\title{
The Role of Indigenous Knowledge in Climate Change Adaptation: The Case of Gibe Woreda, Hadiya Zone, Ethiopia
}

\author{
Habtamu Dagne Bogale*, Samuel Shibeshi Bikiko \\ Email address: \\ dagnehabtamu@gmail.com (H. D. Bogale), sshibeshi@gmail.com (S. S. Bikiko) \\ ${ }^{*}$ Corresponding author
}

Department of Geography and Environmental Studies, College of Social Sciences and Humanities, Wachemo University, Hosanna, Ethiopia

\section{To cite this article:}

Habtamu Dagne Bogale, Samuel Shibeshi Bikiko. The Role of Indigenous Knowledge in Climate Change Adaptation: The Case of Gibe Woreda, Hadiya Zone, Ethiopia. International Journal of Environmental Protection and Policy. Vol. 5, No. 6, 2017, pp. 104-113. doi: 10.11648/j.ijepp.20170506.14

Received: August 2, 2017; Accepted: August 16, 2017; Published: January 3, 2018

\begin{abstract}
This study was focused on the role of indigenous knowledge in climate change adaptation in Gibe woreda, hadiya zone, Ethiopia. The woreda organized in to 24 kebles, from these the researcher have been used six kebeles as a representative based on stratified sampling techniques through agro ecological zone. 213 farmers' households were selected from different agro - ecology zones through simple random sampling technique and development agents were involved in the study. The objectives of this study ware examining the perception of farmers and agricultural experts towards climate change, the impacts of climate change/variability on productivity of agriculture and investigate the indigenous knowledge used by the local community responding to climate change. Primary and secondary data and questioner, interview, FGD and field observation were used. Books, unpublished materials were used as a secondary data. Southern nation nationality and people's metrology agency bureau was another source of metrological data for this study. There is a significant relationship between farming experience and perceptions of farmers towards temperature changes and farming experience, agro-ecological zone with perceptions of farmers to wards rainfall change. $81 \%$ of the respondents reveled they faced a great climate change related problems in their life such as Shortage of pasture land, crop yield reduction, Loss of livestock, flooding and Drought. Generally, most of the farmer's dependents on their own local knowledge for understanding and evaluating climatic change and weather variation in globally and locally because of lack of metrological information and resulted for lack of awareness to used different medias to know about the day to day weathering phenomenon. Different stakeholders should be develop appropriate strategies for reducing vulnerability of agricultural production to climate change by supporting the farmers use and developing their indigenous knowledge combining with introduced adaptation mechanisms to improve local adaptation system of climate change and variability.
\end{abstract}

Keywords: Climate Change, Climate Variability, Adaptation, IK

\section{Introduction}

Climate change is one of the development challenges in addition to the existing problems like food insecurity, poverty and HIV/AIDS. The impacts, caused by past emissions of greenhouse gases, will be inevitable in Ethiopia regardless of global, regional and national mitigation efforts like disaster risk reduction (H. E. Bashir Abdullahi, 2009). The gross national product (GNP) of Ethiopia, for example, declines significantly during droughts because of the high contribution of agriculture to the economy (World Bank, 2006).

Climate change may be a global phenomenon, but the impacts will not be evenly distributed among the world's population. Indigenous groups are projected to be among the communities most heavily affected by climate change (Parrotta and Agnoletti 2012).

The likely impacts of climate change in Africa will add to these existing stresses and exacerbate the effects of land degradation. Increased temperature levels are expected to 
cause additional loss of moisture from soil, reduced and more intense rainfall and higher frequency and severity of extreme climatic events, such as floods and droughts. These factors are already leading to a loss of biological and economic productivity and putting population in dry land Africa at risk of short- and long-term food insecurity ( Kiros Meles and Desta Gebremichael, 2013).

The increases in temperature and changes in precipitation patterns in Ethiopia and other parts of Africa can change the spatial and temporal distribution of water and nutrients, increase natural disturbances, changes natural processes, modify ecosystem structure and functioning, and change the distribution of plant and animal species (Adger and Brown, 1994).

Adaptation is an important component of climatic change impact and vulnerability assessment and is one of the policy options in response to climatic change impacts (Smith JB, S Lenhont, 1996 and Fankhauser S., 1996). Adaptation to climatic change is therefore critical and of concern in developing countries, particularly in Africa where vulnerability is high because ability to adapt is low (Hassan R, Nkemechena C, 2008).

The IPCC's Fourth Assessment Report (AR4) noted that 'indigenous knowledge is an invaluable basis for developing adaptation and natural resource management strategies in response to environmental and other forms of change (Parry et al., 2007).

Researches on Indigenous Knowledge in Climate Change Adaptation have been conducted for many years in all over the world and in Ethiopia. For instance in Ethiopia, Indigenous knowledge practices for climate change adaptation and impact mitigation has been conducted by Kiros Meles and Desta Gebremichael (2013) in Tigray, and Role of indigenous knowledge in climate change adaption was described in Gebre Michael and Kifle (2009). But still there is a limitation of study on the role of indigenous knowledge in climate change adaptation in Ethiopia, specifically Hadiya zone. So, the main purpose of this study was assessed the Role of Indigenous Knowledge in Climate Change Adaptation the case of Gibe woreda, Hadiya zone, Ethiopia.

\section{Objective of the Study}

The overall objective of this study was assessing the Role of Indigenous Knowledge in Climate Change Adaptation in Gibe woreda, Hadiya zone.

Specific objectives

i. To examine the awareness and perception of farmers and local authorities, experts in the field of agriculture and natural resource management towards climate change.

ii. To examine the impact of climate change on agricultural production. iii. To investigate the indigenous knowledge used by the local community responding to climate change.

\section{Research Question}

i. What look like the awareness and perception of farmers and local authorities, experts in the field of agriculture and natural resource management towards climate change?

ii. What are the impacts of climate change on socio economic activity?

iii. What are the indigenous knowledge used by the local community responding to climate change.

\section{Significant of the Study}

Understanding the IK role in responding to climate change is one of the most important to increase the productivity what types of changes are to be expected in the future, the forces and processes behind its changes and its implications on the livelihoods of the surrounding rural areas. Therefore, this study will be helpful to Gibe Woreda administrator, natural resources managers, development agents, fund providers, socio economic development planners, public administrators and environmentalists to have the firsthand and methodological research about any related issues in the area. Particularly, the local community will be most benefited as this study may be a bench mark for any development intervention and emergency works for the government and NGOs.

\section{Materials and Methods}

\subsection{Description of the Study Area}

The Gibe district is located at Hadiya zone of Southern Nation Nationalities and regional state /SNNRS/, southern part of the country. It situated at $260 \mathrm{Km}$ south of Addis Ababa and $30 \mathrm{Km}$ South West Hossana town. Geographically it lies at 7037 '53" -7042 '43"N Latitude and 37037'07"-370 44 '25" E Longitudes. Average rain fall from 600 to 1200 $\mathrm{mm}$. The total area of Gibe woreda is 44783 ha.

Gibe woreda has a Kola, Woynedega and Dega climatic characteristics with the mean annual rainfall range from 600 to $1200 \mathrm{~mm}$. The rainfall in the woreda is bimodal, which is locally called belg and meher. The mean annual temperature ranges from $17.6^{\circ} \mathrm{C}$ to $25^{\circ} \mathrm{C}$.

The area coverage of the land use system indicates that $69.8 \%$ is cultivated lands, $14.5 \%$ is forest lands, $8.4 \%$ is grazing lands and $7.3 \%$ is others. The main annual crops grown in the area under the rain fed system are wheat (Triticum aestivum), barley, maze (Zea mays L.), Teff (Eragrostis teff) and sorghum. 


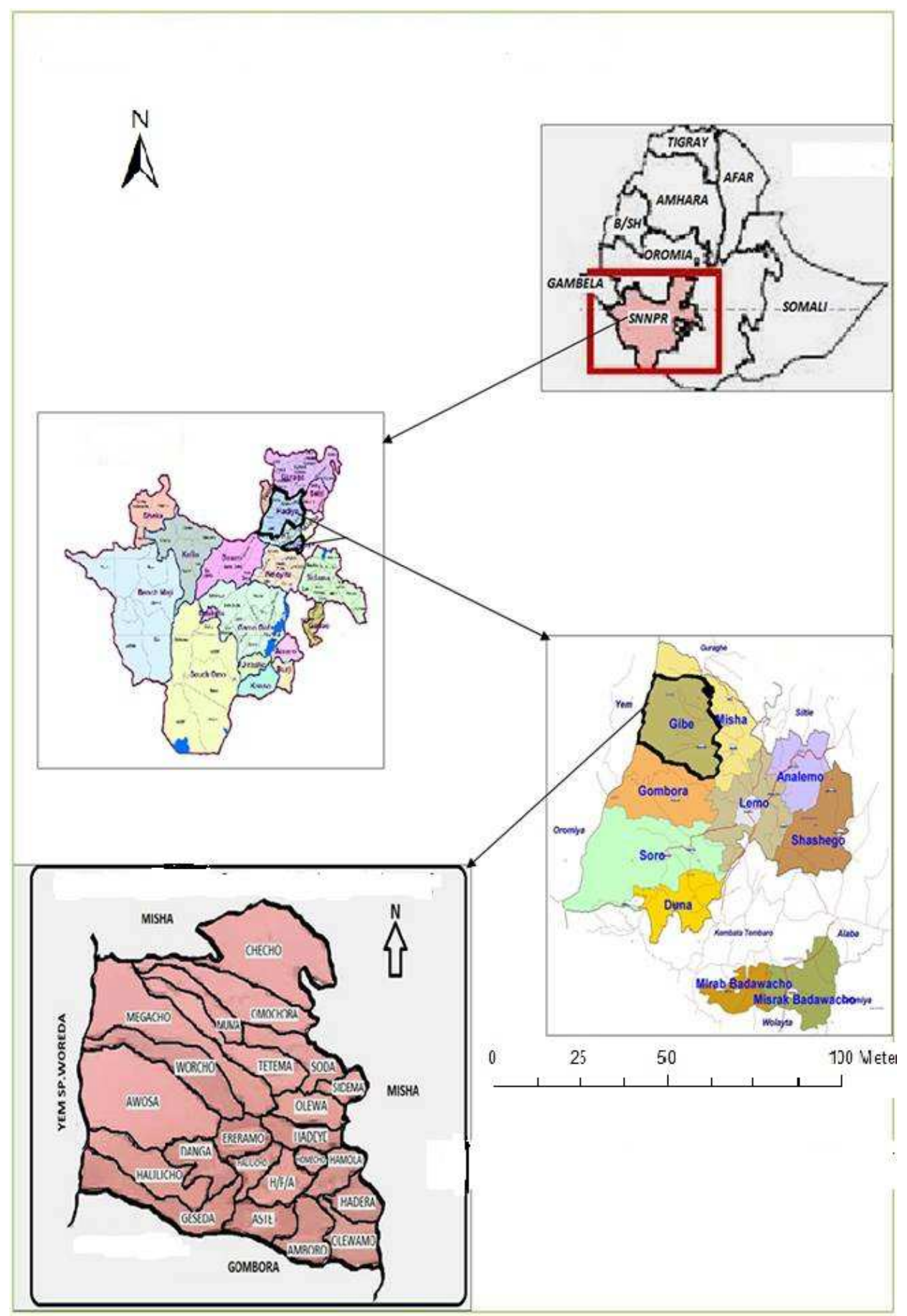

Figure 1. Map of, Gibe Woreda, Haddya zone, Ethiopia.

\subsection{Sampling Technique}

There are eleven woredas which are found in Hadiya zone, from these worads Gibe woreda were selected as the study area randomly. Multi stage sampling techniques was used to select sample households. First by using stratified sampling technique 24 kebles of gibe woreda were categorized into 3 strata. The stratum was based on agro ecology (dega, w/dega and kola). Second from each agro ecological zone two kebles were selected through simple random sampling technique. From the total 24 kebeles of gibe woreda 6 kebeles were selected from this woreda through simple random sampling technique. Third, another stratum was formed based on sex means that; each representative kebeles were grouped into male headed and female headed farmers. Finally, simple random sampling technique was used to select sampled households from each stratum.

Out of the total households of sampled kebeles (4212 households) the researcher was used 5\% (213) households as a sample. From the total sampled households $91 \%$ (194) were male households and $9 \%$ (19) were female households.

Key informants were selected both from households and 
agricultural experts for interviews.

Focus Group Discussions

FGDs using semi-structured guidelines were carried out with groups of pre-selected respondents of heterogeneous categories. The guidelines were prepared for each group. Four groups were formed and five Participants from each group for FGDs were selected based on their gender, age, availability, and willingness to participate.

Out of the total participants (12) were males and (5) were females households and 3 agricultural experts were selected for focus group discussion.

\subsection{Methods of Data Analysis}

The data collected through questionnaire were analyzed through different statistical techniques. In this research descriptive statistics such as percentages, mean values and frequency tables was apply to organize and analyze the data. In addition to this, inferential statistical techniques such as chi-square test were used to understand wither is there any relationship between different variables (educational level, farming experience and agro climatic zone) with perceptions of the local peoples towards climate change. All the aforementioned quantitative techniques were employed using Statistical Package for Social Sciences (SPSS version 20.0) software.

Information obtained from focus group discussion, field observation and interviews with key informants of the village and agricultural extension officer were analyzed through narration/description way.

\section{Result and Discussion}

\subsection{Farmers' Understanding About Climate Change/ Variability}

Based on the study $61.03 \%$ of respondents were not heard about Climate Change and $38.96 \%$ of participants were heard information about the issues. The respondents who have access of information about climate change their main sources of information were government agencies/information (53.84\%), friends/ families (31.53\%), radio $(10.76 \%)$, and Television (TV) (3.84\%) respectively.

In this part the researcher is discussed on the level of understanding of farmers about climate change based on their educational level. Because different studies assured that level of education is one of the main determinant factors people's perceptions in different aspects including climate change. out of the total of able to only read and write respondent majority $(64.36 \%)$ were answered that the term climate change means Flood/heavy flood, Storm/cyclone, Drought Irregular rainfall, High temperature and heavy rainfall. And also similar to this $14.94 \%, 6.89 \%, 5.74 \%, 4.59 \%$ and $3.44 \%$ of respondents in this category believed that the term climate change is Flood/heavy flood, High temperature, Drought Irregular rainfall, Storm/cyclone and Heavy rainfall sequentially. Likewise the above out of the total respondents, $35.71 \%$ (primary educational level), $48.14 \%$ (Secondary level) and
$53.33 \%$ (college/university graduate) respondents answered for the same question, the term climate change means Flood/heavy flood, Storm/cyclone, Drought Irregular rainfall, High temperature and heavy rainfall.

Out of the total participants of the study the majority respondents $(84.65 \%)$ of them experienced that, there is climate variability in the study area. Some of the respondents (9.4\%) believed that the climate of the study area has totally changed and $2.48 \%$ of the respondents the climate has not changed or it is stagnant. Therefore, from this analysis, the local peoples experienced that there is climate change and variability in the study area. According to the FGD the farmers experienced the climate in some extent changed.

\subsection{Perceptions of Farmers, Local Authority and Experts towards Climate Change}

\subsubsection{Farmers Perception on Temperature Changes by Farming Experience}

Table 1. Perception of changes in temperature by farming experience.

\begin{tabular}{lllll}
\hline \multicolumn{5}{c}{ Perception of changes in temperature (\%) } \\
\hline $\begin{array}{l}\text { Farming } \\
\text { experience }\end{array}$ & Increased & decreased & $\begin{array}{l}\text { No observable } \\
\text { change }\end{array}$ & $\mathbf{X}^{\mathbf{2}}$ \\
\hline$<=10$ years & 7.3 & 0 & 50 & \\
11-20 years & 15.18 & 11.1 & 25 & 0.000 \\
21-30 years & 17.9 & 77.8 & 16 & $(\mathrm{df}=8)$ \\
31-40 years & 28.8 & 11.1 & 9 & \\
$>40$ years & 30.9 & 0 & 0 & \\
\hline
\end{tabular}

Sig=0.05, Source: field survey, 2016

So, based on the above table, farmers which have a long farming experience ( $>40$ years and $31-40$ years) perceived that there is change in temperature patterns in the last 20 years in the study area. But majority of farmers which have low farming experience ( $<=10$ years and $11-20$ years) perceived that no observable changes in temperature. So, from this analysis we can concluded that, if the farming experience increases, the local peoples can able to perceived and observe the real changes of temperature amounts in the study area.

\subsubsection{Farmer's Perception on Temperature Changes by Agro-climatic Zone}

In this study the chi square test analysis indicated that, there is no significant relationship between agro-climatic zone and perception of local peoples on temperature changes in the study area.

Table 2. Perception of changes in temperature agro-climatic zone.

\begin{tabular}{lllll}
\hline \multirow{2}{*}{$\begin{array}{l}\text { agro-climatic } \\
\text { zone }\end{array}$} & \multicolumn{4}{l}{ Perception of changes in temperature (\%) } \\
\cline { 2 - 5 } & Increased & decreased & $\begin{array}{l}\text { No observable } \\
\text { change }\end{array}$ & $\mathbf{X}^{\mathbf{2}}$ \\
\hline Dega & 32.5 & 27.8 & 0 & 0.447 \\
W/dega & 26.2 & 16.7 & 25 & $(\mathrm{df}=4)$ \\
Kolla & 41.4 & 55.6 & 75 & \\
\hline
\end{tabular}

$\mathrm{Sig}=0.05$, Source: field survey, 2016

According to the above table 2 the majority peoples who 
live in Dega area and w/dega areas perceived that the variation of temperature is increased $(32.5 \%$ and $26.2 \%)$ but in kola area the majority peoples $(41.4 \%)$ perceived that temperature is increased through time. This implies that the change in temperature occurred in all agro-ecologies.
Therefore, the local peoples which live different agroclimatic zone had no different perception and similar agro climatic zone also had no similar perception about changes of temperature in the study area.

\subsubsection{Perception of Farmers Towards on Rainfall Changes}

Table 3. Perception of rainfall pattern change by agro-ecology.

\begin{tabular}{|c|c|c|c|c|c|c|}
\hline \multirow{2}{*}{$\begin{array}{l}\text { agro-climatic } \\
\text { zone }\end{array}$} & \multicolumn{6}{|c|}{ Perception of changes in rainfall pattern (\%) } \\
\hline & Increased & No observable change & decreased & change in times of raining & I don't know & $\mathbf{X}^{2}$ \\
\hline Dega & 50 & 31.8 & 31.6 & 26.7 & 23.1 & \\
\hline W/dega & 21.9 & 15.9 & 26.3 & 31.7 & 28.2 & $0.036(\mathrm{df}=8)$ \\
\hline Kolla & 28.1 & 52.3 & 42.1 & 41.7 & 48.7 & \\
\hline
\end{tabular}

Sig=0.05, Source: field survey, 2016

According to the above table 3 , the majority peoples (50\%) who live in Dega area believed that there is increasing of rain full amount but in kola area the majority peoples (42.1\%) perceived that decreasing of rainfall pattern in the study area. This implies that likewise the change in temperature variation rainfall pattern also occurred in all agro-ecologies. Therefore, the local peoples which live different agro-climatic zone had different perception towards rainfall pattern in the study area.

The local farmers able to understand the variation of rainfall based on their farming experience. So, the following test result indicated a significant difference between the view of experienced and inexperienced farmers existed in rainfall change perceptions. The number of respondents perceived increased in rainfall pattern seems to decrease as farming experience increased. On contrast, the number of participants felt decreased in rainfall pattern seemed to increase as farming experience increased.

Table 4. Farmer's perception on precipitation by farming experience.

\begin{tabular}{|c|c|c|c|c|c|}
\hline \multirow[b]{2}{*}{ Farming experience } & \multicolumn{5}{|c|}{ Farmer's perception on precipitation (\%) } \\
\hline & Increased & decreased & No observable change & I don't know & $\mathrm{X}^{2}$ \\
\hline$<=10$ years & 34.4 & 11.1 & 39 & 35.9 & \\
\hline $11-20$ years & 37.5 & 13.9 & 24.4 & 17.9 & \\
\hline $21-30$ years & 28.1 & 16.7 & 26.8 & 20.5 & $0.000(\mathrm{df}=16)$ \\
\hline $31-40$ years & 0 & 19.4 & 9.8 & 0 & \\
\hline$>40$ years & 0 & 38.9 & 0 & 25.6 & \\
\hline
\end{tabular}

Sig=0.05, Source: field survey, 2016

\subsection{Impact of Climate Change on Agricultural Production}

The country has a history of experiencing climate extremes, such as droughts and floods, increasing temperature, and unreliable rainfall (NMA, 2007).

About $88.7 \%$ responded that they faced climate related disaster over the last 20 years. According to the following figure recurrent drought, erratic rainfall, food, crop pests and diseases were the major climate related shocks happened over the last 20 years in the study area.

Climate change/variability imposed great influences on overall activities of human being globally. This impact also influences the day to day activities of the local peoples found in the study area. Based on the result most of the respondents $(81 \%)$ believed climate change /variable have been a great impact on different aspect in the study area. And also (7.9\%) of farmers responded the impact of climate change /variability would moderate and (10.8\%) of participants were not understand its impact on their life.

Table 5. Major challenges of climate change/variability.

\begin{tabular}{lll}
\hline major challenges & Frequency & Percentage \\
\hline Shortage of pasture land & 32 & 15 \\
crop yield reduction & 44 & 20.7 \\
Loss of livestock & 4 & 1.9 \\
Flooding & 4 & 1.9 \\
Drought & 10 & 4.7 \\
All & 119 & 55.9 \\
Total & 213 & 100 \\
\hline
\end{tabular}

Source: field survey, 2016

Due to climate change the local people faced different problem on their livelihood system. As indicated table 5, about 55.9\% respondents recognized Shortage of pasture land, crop yield reduction, Loss of livestock; flooding and Drought were the major challenges of climate change/ variability in the study area. Based on the FGD because of weather variability some crops were destructs like teff, wheat 
etc. crops were reduces their amount of production from time to time.

And also about $20.7 \%$ of respondents confirmed crop yield reduction was one of the consequences observed in the study area. From this result we can conclude because of climate change the local farmers were challenged their livelihood system.

In the study area Trends of livestock production is decreasing currently due to climate change/variability.
According to the study the reason of decreased livestock production are Shortage of grazing land, Livestock disease, shortage of water for animals and high temperature.

On the FGD majority of the participants agreed in there was change on water quantity and quality/shortage of water, changes on grazing land/drying of grass, death of animal occurred over the past years in the village because of climate change/variability.

\subsection{Climate Change Adaptation Practices in the Study Area}

Table 6. Consider necessary to have adaptation strategies.

\begin{tabular}{lll}
\hline Do you consider it necessary to have adaptation strategies to cope with climate change? & Frequency & Percentage \\
\hline investing resources on adaptation is important & 187 & 87.8 \\
some measures are necessary & 21 & 9.9 \\
only few measures are necessary & 3 & 2 \\
not at all & 213 & 0.9 \\
Total & 213 \\
\hline
\end{tabular}

Source: field survey, 2016

Variability of weather phenomena increase time to time the smallholder farmers have been adjusting their farming system to reduce the harmful impacts on their livelihood strategies. Climate change adaptation depends on the awareness and perception, income level and availability of resources. Based on the survey result $87.8 \%, 9.9 \%$ and $1.4 \%$ of farmers believed that investing resources on adaptation is important, some measures are necessary and only few measures are necessary sequential to cope with climate change. In the FGD the farmers agreed all of the societies should take responsibilities as a land owner by working together.

As the indicated in figure 2, about $42.25 \%$ of participant's farmers across sampled kebeles have applying new cropping system and irrigation to cop up the occurrence of climate change.

\section{the possible adaptation methods to minimize the impacts of climate change}

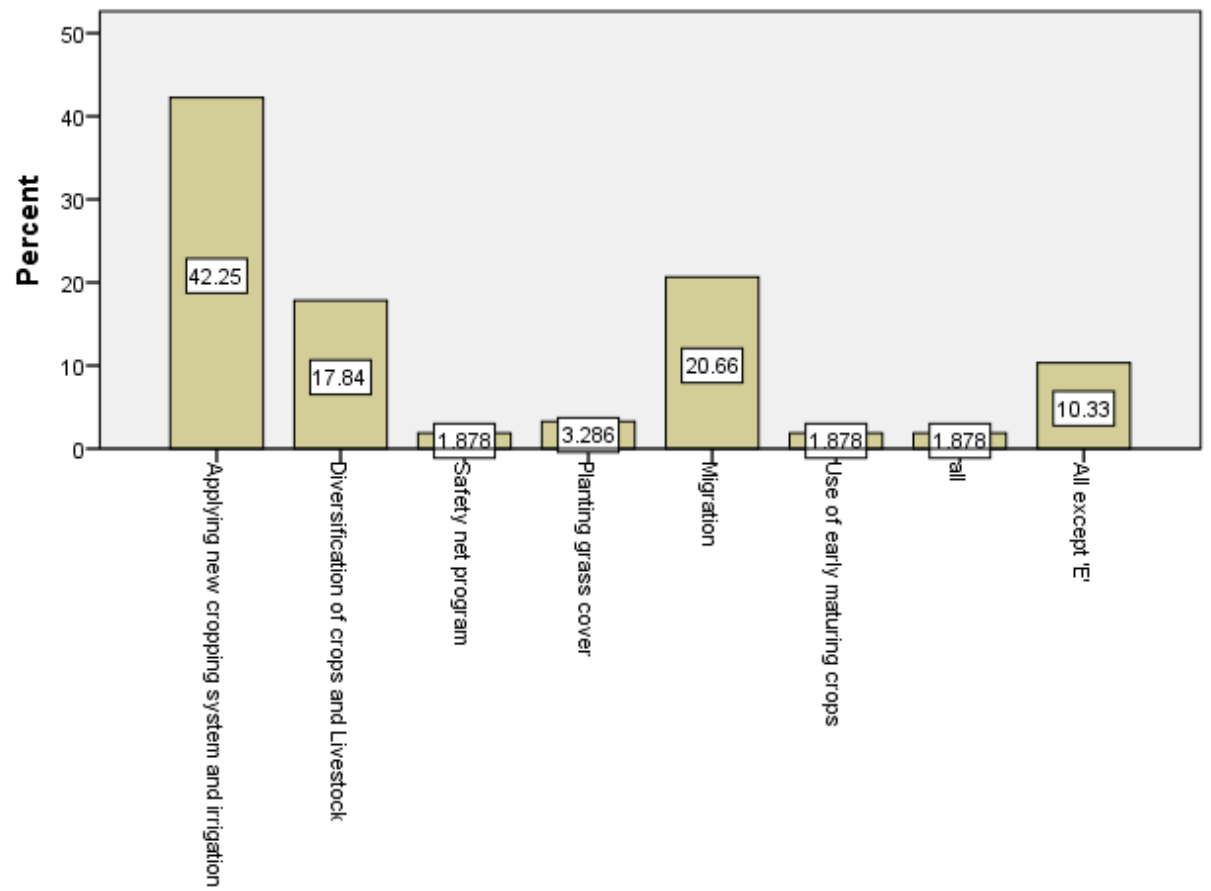

Figure 2. The Possible Adaption Methods to Reducing the Impact of Climate Change, Source: field survey, 2016.

$20.66 \%$ of respondents have using migration as alternative strategies to cop up the impact related to weather variation. According focus group discuss and key informant interview, most young farmers were migrated to South Africa, Addis Ababa and also hosanna to evacuate the problem. And also $17.84 \%$ of respondents were using crop diversification and 
livestock as much as possible. In addition, planting grass cover, including in safety net program, use of early maturing crops were another mechanism to resisting climate change impacts.

One of the means of adapting the impact of climate change/variability used by the farmers of the study area was diversifying means of earning income from farm to non-farm activities. During FGD most of respondents said they used diversified means of income from farm to non-farm activities, soil and water conservation measures in the farm lands, reserving water from rain to be used for minor irrigation during dry seasons and community based measure to overcome the observed climate change/variability impacts.

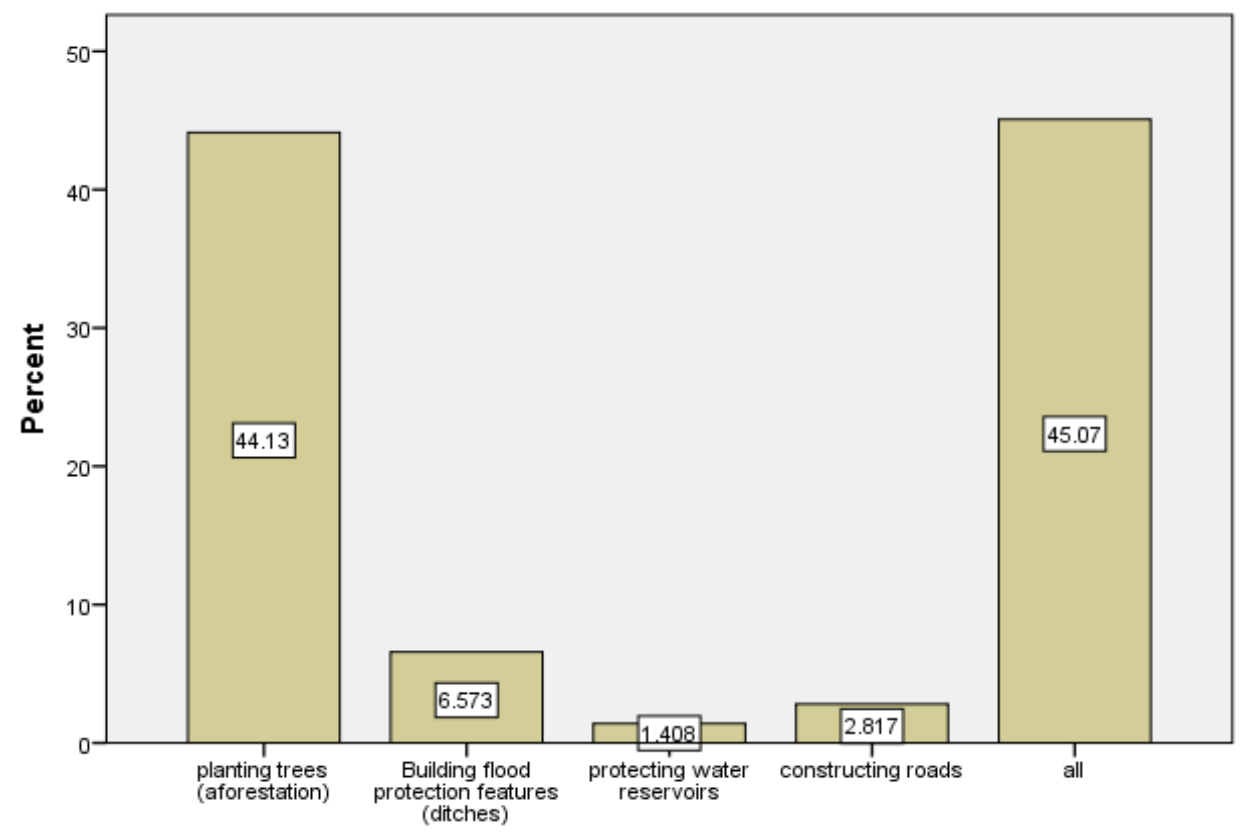

Figure 3. Measure have taken to overcome climate variability problem, Source: field survey, 2016.

Different practices that farmers currently implementing to improve their farming activities are shown figure 3, about $45.07 \%$ the participant farmers' use planting trees (aforestation), building flood protection features (ditches), protecting water reservoirs and constructing roads were a mechanisms used by farmers to overcome climate variability problem. In addition to those mechanisms, the local people also employed tracing, seed conserving, natural resources conservation and small scale irrigation to reduce climate change related problems.

Table 7. Adaptation related with shortage of water.

\begin{tabular}{lll}
\hline $\begin{array}{l}\text { Adaptation related with shortage of } \\
\text { water }\end{array}$ & Frequency & Percentage \\
\hline Rain water harvesting & 67 & 31.45 \\
Use of recharging groundwater & 36 & 16.9 \\
Expanding irrigable farm & 48 & 22.53 \\
Use of reservoirs and ponds & 62 & 29.1 \\
Total & 213 & 100 \\
\hline
\end{tabular}

Source: field survey, 2016

Climate change/variability also impact on water resources. So, the farmers of the study area employed different mechanisms to coping up from shortage of water because of climate change. As table 7 showed 31.5\%, 29.1\%, 22.53\% and $16.9 \%$ of farmers used Rain water harvesting, Use of reservoirs and ponds, Expanding irrigable farm and Use of recharging groundwater as a cop up mechanisms from water scarcity because o climate change/variability.

According to the survey report collected from the study area farmers have been using different coping mechanism of climate change impact on livestock production.

Table 8. Strategies used to overcome climate change impacts on livestock production.

\begin{tabular}{lll}
\hline $\begin{array}{l}\text { major coping strategies used to } \\
\text { overcome climate change / variability } \\
\text { impacts on livestock production }\end{array}$ & Frequency & Percentage \\
\hline $\begin{array}{l}\text { Increase livestock diversification } \\
\begin{array}{l}\text { Seasonal migration with your cattle in } \\
\text { search of pasture \& water }\end{array}\end{array}$ & 65 & 30.5 \\
$\begin{array}{l}\text { Decreasing the number of livestock } \\
\text { (Sale of weak and old animals before the }\end{array}$ & 123 & 11.7 \\
$\begin{array}{l}\text { dry season etc.) } \\
\text { Total }\end{array}$ & 213 & 57.7 \\
\hline
\end{tabular}

Source: field survey, 2016

As table 8, showed $57.7 \%, 30.5 \%$ and $11.7 \%$ of respondents undertake adaptation measures of decreasing the number of livestock such as Sale of weak and old animals before the dry season, Increase livestock diversification and Seasonal migration with their cattle in searching of pasture \& water are the major coping mechanisms used by farmers of the study area respectively.

Even though the farmers used different cop up mechanisms to alleviate climate change related problems, they couldn't resist and rehabilitate totally from climate 
change and variability impacts. So, different stakeholders could participate in different ways in the study area. Based on the survey result, majority $(44.1 \%)$ of farmers were supported by Government safety net program in the woreda and $8.9 \%$ of the respondents also gained different support from NGOs like SLM organization.

Table 9. Means of gaining supports in the study area.

\begin{tabular}{lll}
\hline $\begin{array}{l}\text { Means of gaining supports cop up from } \\
\text { climate change problems }\end{array}$ & \\
\hline Self-resilience & 79 & 37.1 \\
Assistance from the society/community level & 5 & 2.3 \\
Government safety net program & 94 & 44.1 \\
Assistance from international donors & 16 & 7.5 \\
Assistance from NGOs & 19 & 8.9 \\
Total & 213 & 100 \\
\hline
\end{tabular}

Source: field survey, 2016

During the occurrences of shocks related climate change and variability, $37.1 \%$ of the farmers were able to resist the problem themselves (self-resilience). In addition to this the researcher also tried to collect information about needs of local people to adapt the problems they faced during the last natural disaster. Based on the interview results, during the occurrences of climate change/variability related problems in the last time in the study area the local peoples were needed; agricultural inputs and foods, direct cash, training, technology, linkage and information to cop up from the problem.

\subsection{Indigenous Strategies Used to Adapt Climate Change}

At the study site, there were some local coping and adaptation strategies adopted in response to observed risks and hazards related to climatic factors. Most of the coping activities were found to be event specific based on local knowledge and innovations, because most of the respondents were not aware about actual impacts of climate changes.

Table 10. Indigenous strategies used to adapt climate change.

\begin{tabular}{|c|c|c|c|c|c|c|c|}
\hline $\begin{array}{l}\text { Land management } \\
\text { strategies }\end{array}$ & Percentage & $\begin{array}{l}\text { Crop management } \\
\text { strategies }\end{array}$ & Percentage & $\begin{array}{l}\text { Livestock management } \\
\text { strategies }\end{array}$ & Percentage & $\begin{array}{l}\text { Off- farm } \\
\text { activities }\end{array}$ & Percentage \\
\hline Manuring & 56.05 & Crop diversification & 23.56 & $\begin{array}{l}\text { Production and sale of } \\
\text { livestock }\end{array}$ & 47.8 & $\begin{array}{l}\text { Charcoal } \\
\text { production }\end{array}$ & 53.71 \\
\hline Mulching & 21.01 & Crop rotation & 26.75 & & & Petty trading & 27.38 \\
\hline Fallowing & 14.64 & Mixed farming & 32.48 & & & Daily laborer & 12.73 \\
\hline \multirow{2}{*}{$\begin{array}{l}\text { Raising of mounds } \\
\text { and ridging }\end{array}$} & \multirow{2}{*}{8.28} & Pest and weed control & 5.09 & & & & \\
\hline & & Timing of planting & 12.1 & & & & \\
\hline Total & $100(157)$ & & $100(157)$ & & $100(157)$ & & $100(157)$ \\
\hline
\end{tabular}

Source: field survey, 2016

The study found that the local people used different indigenous strategies to adapt the current climate change such as Land management strategies, Crop management strategies, Livestock management strategies and off-farm activities. Farmers employed different indigenous strategies to management their land like Manuring (56.05\%), Mulching (21.01\%), Fallowing (14.64\%) and Raising of mounds and ridging $(8.28 \%)$.

In the case of Crop management strategies the farmers used Mixed farming, Crop rotation, Crop diversification, Timing of planting and Pest and weed control respectively as indigenous strategies to overcome the climate change problem. In addition to this, adapting climate related impacts on Livestock production the local peoples practiced Production of livestock through modern highbred system and sale of livestock reducing the number of animals to alleviating shortage of foods because of climate change. Even though the farmers have employed different indigenous adaptation mechanisms, they couldn't able to resist the impact. So, farmers enforced searching another coping mechanisms like off- farm activities. $53.71 \%, 27.38 \%$ and $12.73 \%$ of participants were used Charcoal production, Petty trading and Daily laborer respectively as indigenous climate change adaption mechanisms.

\subsection{Institutional Coping Mechanisms}

In climate change adaptation different stakeholders have been participated in Ethiopia. In the study area also Different governmental and non-governmental institutions have been participating on various climate change adaptation program in the society. Ethiopia food security safety net program is one of governmental programs that provide different support to the farmers contributes to upsurge the adaptive capacity of the farmers from climate change impacts. According to Haddiya zone of gibe woreda safety net program office for the year 2009e.c 9574 number of farmers were supported with the program. This program supported the local peoples in different ways (in cash, material and building of different infrastructures). From these some of them are: bio physical soil and water conservation, forestry, agro-forestry and forage development, water projects (community and micro level construction), community road earth construction and rehabilitation, small scale irrigation construction and rehabilitation, social infrastructural activities construction and nutrition based activities.

In addition to this program, SLM is also nongovernmental organization which participated on climate change/ variability adaptation program in gibe woreda. SLM 
organization like wise safety net program, it also participated on different activities But it differ from safety net program because of stressed on conservation of the natural resources special sustainable land management. According to gibe woreda SLM coordinator, different activities were doing by this program to build up the capacity of the farmers and able to cop up from climatic related shock.

From these activities SLM have doing like developing small scale irrigation, building of the rain water harvesting mechanisms, developing streams for ready for household consumption. SLM also participated in creating awareness of farmers on soil conservation system, farming mechanisms and how to rehabilitate degradable land though aforstation program by giving training. Some of the activities have been doing by safety net program office and SLM organization to support the farmers ere the following.

\section{Conclusion}

Majority of farmers were not heard about climate change because of poor access to climatic information but some of the respondents would have information of this global phenomenon and their main sources of information were government agencies/information, friends/ families, radio.

Farmers and other stakeholders like DA, different agricultural experts etc. were more or less familiar with the term climate change. Though, the understanding of climate change and variability causes and consequences varied widely among in the local peoples. Many respondents $(64.36 \%)$ understand climate change means Flood/heavy flood, Storm/cyclone, Drought Irregular rainfall, High temperature and heavy rainfall. Even though most of the participants were illiterate, they would understand and define climate change and variability in different ways this was because of their lifelong experiences attached with the natural environment.

According to the study most of the study area farmers experienced the presence of climate change and variability. It means they fell increasing of temperature and number of hot days and fluctuations of rain full amount in the study area over the last 20 years.

The chi-square test revealed the perception of farmers in climate change and variability significantly varies across farming experience and agro- climatic zone. Most of the farmer's perceptions towards temperature changes were almost similar with the temperature and rainfall records of metrological data.

Climate change and variability imposed great influences on over all activities of farmers in the study area. $81 \%$ of the respondents reveled they faced a great climate change related problems in their life. The major problems were: Shortage of pasture land, crop yield reduction, Loss of livestock, flooding and Drought.

Crop production and rearing of livestock was the major livelihood sources in the study area but Because of climate change and variability there was fluctuations in crop production and productivity of animal. Yields were very low and many households were unable to fulfill their annual food requirement from their own production. They tried to survive with governmental and nongovernmental supporters. The major causes for reduction of crop production were soil fertility reduction, erratic rain fall, unpredictability of rainfall, pest and diseases and also high prices of agricultural inputs. And also Shortage of grazing land, Livestock disease, shortage of water for animals and high temperature were the main factors that affect animal production in the study area.

Farmers tried to employed different adaptation mechanisms resisting impacts of climate change and variability. About $42.25 \%$ of participant's farmers across sampled kebeles have applying new cropping system and irrigation to cop up the occurrence of climate change. According focus group discuss and key informant interview, most young farmers were migrated to South Africa, Addis Ababa and also hosanna to evacuate the problem. And also $17.84 \%$ of respondents were using crop diversification and livestock as much as possible. In addition, planting grass cover, including in safety net program, use of early maturing crops were another mechanism to resisting climate change impacts. $45.07 \%$ the participant farmers' use planting trees (aforestation), building flood protection features (ditches), protecting water reservoirs and constructing roads were a mechanisms used by farmers to overcome climate variability problem. Additionally, decreasing the number of livestock such as Sale of weak and old animals before the dry season and Increase livestock diversification were the coping mechanisms of farmers in the study area.

Another impact of climate change and variability in the study area peoples faced scarcity of water resources. So, the farmers used Rain water harvesting, Use of reservoirs and ponds, Expanding irrigable farm and Use of recharging groundwater as a cop up mechanisms.

In order to adjust their cultivation system farmers used the seasonal variation of temperature and rain amount in their locality. Based on the result $89.2 \%$ of farmers was Prevalence of human and animal diseases that are not familiar to the area used to evaluate the Temperature Trend of The study area. Increased drought and flood frequency, loss of some plants and animal species, comes of rainfall early or late, decline of soil productivity/fertility shortened of growing period and decline of agricultural yields were used as indicators to evaluate the rainfall patterns in the study area.

Generally, most of the farmer's dependents on their own local knowledge for understanding and evaluating climatic change and weather variation in globally and locally because of lack of metrological information and resulted for lack of awareness to used different medias to know about the day to day weathering phenomenon.

The farmers adapting system the changing climate might not be effective because of different barriers. most of the farmers $(46.9 \%)$ responded that their main constraints to adapt impacts of climate change/variability were lack of awareness, shortage of money, Lack of accessibility to infrastructure, Poor market accessibility and Low and 
fluctuation of prices respectively. in addition to this from FGD and key in formant interview participant's said lack of accessible to water, credit or saving, knowledge, information about weather and climate variation, land scarcity and lack of agricultural technologies were identified as a major barriers to adaption of climate change/variability.

\section{Recommendation}

i. Different stake holders like agricultural extension experts, development agents, local government etc should participate for disseminating early metrological output information about climatic conditions. Those stake holders should develop early warning system And also the farmers should integrated this early warring information with their local indicators to resist the coming seasonal and daily variation of weather futures.

ii. The zonal and woreda agricultural office should give continuous training to the farmers about climate change and variability, conservation and preservation natural environment to create awareness and to have a good perception of farmers enhancing natural resources conservation practices.

iii. should be develop appropriate strategies for reducing vulnerability of agricultural production to climate change by supporting the farmers use and developing their indigenous knowledge combining with introduced adaptation mechanisms to improve local adaptation system of climate change and variability.

iv. Still the farmers are total relays on local knowledge and indicators to understand rainfall and temperature variation in the area. So, any stakeholders should improve the quality of metrological data and increasing the number of station with spatial distribution.

v. Because of climatic change the amount and seasons of rainfall become unpredictable in the study area. So, the farmers should practice short maturing crops and introducing drought resistance crop verities.

vi. Shortage of water is one of the major problems in the study area; the farmers should use rain water harvesting system. And national or regional governments should introduce irrigation technologies to reduce rain feed agriculture dependency and to assured food security.

vii. Even though in the study there are natural resource management practices, but still climatic related catastrophic is occurring. So, soil and water conservation practices are necessary in widely for reducing the influences of climate change and for sustainable productivity of agriculture.

viii. The farmers should diversified livelihood system to minimize the impacts of climatic shocks.
Diversification of the agricultural system like by using multi cropping, mixed farming and improving farming system to more modern and high cash crops. This activities also should supported by agricultural experts and concerned bodies. Different training should prepare in the area of farmers diversifying their income with non-farm activities.

ix. Generally, for sustainable rural development and to secure foods of rural dwellers integrated systems of activities within different governmental and nongovernmental organization should be created to reducing the venerability of agricultural sectors from climatic changing problems and improving the farmer's adaptive capacity.

\section{References}

[1] Adger, W. N., Brown, K., (1994). Land Use and the Causes of Global Warming. John Wiley \& Yukon: threats and opportunities for biodiversity. In: Taylor, E., Taylor, B. (Eds.), Re-sponding to Global Climate Change in British Columbia and Yukon. Environment Canada, Vancouver, BC, pp. 9-1-922.

[2] Fankhauser S. The potential costs of climate change adaptation. In: Smith JB, Bhatt N, Menzhulin G, Benieff M, Budyko, M., Campos, M, et al., editors. Adapting to Climate change: An International perspective. Springer, New York, USA. 1996: 80-96.

[3] H. E. Bashir Abdullahi, 2009. Ethiopia's Commitment to Climate Change Adaptation. A summarized paper prepared for the Earth Day Ethiopia, 22 April 2009.

[4] Hassan R, Nkemechena C. Determinants of African farmers' strategies for adapting to climate changes: multinomial choice analysis. AFJARE. 2008; 2(1)85-104.

[5] Kiros Meles and Desta Gebremichael, (2013). Indigenous knowledge practices for climate change adaptation and impact mitigation: The case of smallholder farmers in Tigray, Northern Ethiopia.

[6] Parrotta, J. A.; Agnoletti, M. 2012. Chapter 13: traditional forest-related knowledge and climate change. In: Parrotta, J. A.; Trosper, R. L., eds. Traditional forest-related knowledge: sustaining communities, ecosystems and biocultural diversity. Dordrecht, The Netherlands: Springer: 491-534.

[7] Parry M. L., Canziani, O. F., Palutikof, J. P., van der Linden, P. J. and Hanson, C. E. (eds.) 2007. Contribution of Working Group II to the Fourth Assessment Report of the Intergovernmental Panel on Climate Change. Cambridge, UK and New York, Cambridge University Press.

[8] Smith JB, S Lenhont. Climate change adaptation policy options. Climate Research. 1996; 6: 193-201. Sons, New York.

[9] World Bank, (2006). Ethiopia: Managing Water Resources to Maximize Sustainable Growth. REPORT NO. 36000-ET. 